\title{
Argumentos de professores de química e física sobre modelos de ensino: aspectos estruturais, dialéticos e retóricos
}

\author{
Adjane da Costa Tourinho e Silva \\ adtourinho@terra.com.br \\ 0000-0001-8996-0689 \\ Universidade Federal de Sergipe, \\ São Cristóvão, Sergipe, Brasil. \\ Roberto Nardi \\ nardi@fc.unesp.br \\ 0000-0002-5018-3621 \\ Universidade Estadual Paulista Júlio \\ de Mesquita Filho, Bauru, São \\ Paulo, Brasil.
}

\begin{abstract}
RESUMO
Neste artigo, apresentamos uma discussão sobre a estrutura e a qualidade dos argumentos elaborados por professores de Química e Física sobre temas da Educação em Ciências. O protocolo de obtenção dos dados da pesquisa correspondeu a asserções sobre as quais os sujeitos tiveram que expressar seus pontos de vista, justificando-os. Os dados escritos foram analisados de acordo com o Padrão de Argumento de Toulmin, porém recolocando-o na densidade de um discurso situado. Os argumentos produzidos foram comparados entre si e caracterizados em sua qualidade tendo em vista os aspectos estruturais dialéticos, bem como os retóricos. Além de uma estrutura básica de argumento, foram encontrados argumentos com refutadores, os quais originavam outra estrutura argumentativa com apresentações detalhadas de dados e conhecimentos de base. Foram verificados, ainda, elementos que puderam ser percebidos como característicos da dimensão do pathos e do ethos, na perspectiva da argumentação enquanto persuasão.
\end{abstract}

PALAVRAS-CHAVE: Argumentos. Características e qualidade de argumentos. Educação em ciências. 


\section{INTRODUÇÃO}

Nas últimas décadas, no campo da Educação em Ciências, o interesse pela linguagem e interações discursivas que se desenvolvem no plano social da sala de aula tem se fortalecido, materializando-se em diversas pesquisas e propostas pedagógicas com variados enfoques. Do ponto de vista do entendimento acerca da construção de novos significados neste espaço, a interação emerge como unidade de análise. Com relação à aprendizagem que se busca promover nos alunos, a linguagem adquire papel fundamental, considerando-se que a apropriação das concepções científicas presume o uso adequado e mesmo frequente de termos que lhes são característicos. Como afirma Lemke (1990), aprender ciência é aprender a falar ciência, o que pode ser entendido como fazer ciência por meio da linguagem que lhe é particular. Portanto, além da apropriação de conceitos-chave, aprender ciências presume a compreensão da sua dimensão discursiva e argumentativa, tendo-se em vista que a Ciência se desenvolve por meio de práticas discursivas específicas, fazendo uso de uma linguagem particular e, portanto, de um modo particular de ver, compreender e falar sobre o mundo.

Considerando-se que as práticas argumentativas são uma atividade central na Ciência, justifica-se a inclusão da argumentação como uma atividade central também na Educação em Ciências. Kuhn (1993; 2010), por exemplo, apresenta a noção de "ciência como argumento", ou a visão de que a Educação em Ciência deve proporcionar não apenas o domínio de conceitos científicos, mas a apropriação do discurso científico.

Pensando-se em um processo de ensino-aprendizagem desenvolvido em torno da argumentação, um grande desafio que aí se encontra é prover os professores de estratégias para lidar com as ideias dos alunos e fomentar a argumentação em suas aulas. Como discutido por Duschl (2008), isso envolve uma mudança do foco de ensino sobre o que o aluno conhece para como o aluno conhece e por que ele acredita que conhece, envolvendo uma diferente cultura de sala de aula e de ambiente de discurso.

É importante considerar, portanto, que a argumentação deve ser debatida na formação de professores de ciências. Nesse sentido, os próprios formadores não devem estar alheios a esta prática em suas disciplinas (VIEIRA; NASCIMENTO, 2007), ou seja, não se trata apenas de discutir a argumentação em disciplinas de natureza pedagógica, mas é desejável que a prática argumentativa esteja presente nas demais disciplinas como atividade voltada para a elaboração de um raciocínio crítico. Todavia, a pesquisa sobre a argumentação na formação de professores de ciências ainda é recente e carece de alguns referenciais, sobretudo de ordem analítica (MUNFORD et al., 2005; ZEMBAL-SAUL et al., 2008). Muito se tem discutido nos últimos 25 anos sobre argumentação em salas de aula da Educação Básica, mas poucos estudos se voltam para a argumentação na formação do professor (NASCIMENTO; PLANTIN, 2009).

Tendo-se em vista a importância atribuída à argumentação no ensino de ciências, o papel fundamental do professor no sentido de promover e fomentar o desenvolvimento de práticas argumentativas em suas salas de aula e a carência de pesquisas sobre argumentação voltadas para os professores de ciências quando comparadas àquelas voltadas para os alunos, emergem questões relevantes, tais como: Professores de ciências têm discutido e/ou incorporado estratégias adequadas de argumentação ao longo de sua formação? Quais as estratégias argumentativas utilizadas por professores e futuros professores de ciências quando solicitados a desenvolver e defender seus pontos de vista? Qual a qualidade dos argumentos por eles elaborados?

A fim de contribuirmos para a discussão voltada a tais questões, desenvolvemos uma pesquisa, do tipo estudo de caso, que teve por objetivo analisar as estratégias argumentativas e a qualidade dos argumentos elaborados por professores de ciências em formação continuada em torno de questões da Educação em Ciências. Aliados a este objetivo geral buscamos: Identificar elementos característicos de um discurso 
argumentativo nos textos dos professores, caracterizar as estratégias argumentativas verificadas e comparar tais estratégias quanto ao nível de elaboração.

Por meio de tal pesquisa pretendemos ter acesso à percepção de professores em formação sobre argumentação e formas de articulação de um discurso argumentativo quando solicitados a fazê-lo. O protocolo de obtenção de dados envolveu 3 questões relacionadas a aspectos da Educação em Ciências, aplicadas a alunos de mestrado e graduação de duas universidades públicas: uma da região Nordeste e outra da região Sudeste do país. Todos eles são ligados à Licenciatura em Química ou Física. Os alunos foram solicitados a apresentar e defender seus pontos de vista diante de asserções que Ihes foram propostas. O conteúdo considerado nas asserções está previsto nas ementas de disciplinas normalmente desenvolvidas na graduação e/ou mestrado que tais sujeitos cursaram e/ou estavam cursando no momento da coleta de dados.

Partimos do pressuposto de que a habilidade de argumentação dos professores, bem como a de fomentar a argumentação de seus alunos, é algo fundamental para que sejam instauradas práticas argumentativas em salas de aula de ciências, como tem sido vastamente discutido na literatura da área; todavia, não nos detivemos na análise do discurso argumentativo dos professores em relação a conteúdo específico da Química, Física ou Biologia, como tem sido recorrente, mas a temas da Educação em Ciências, ou seja, estamos interessados na habilidade dos professores em articular um bom discurso argumentativo relacionado às ciências, mas não especificamente ou estritamente abordando conteúdos dessas disciplinas. Consideramos que a capacidade argumentativa dos professores deve ser investigada também em outros domínios do conhecimento relacionados à sua profissão que não sejam somente aqueles que envolvem os conteúdos que trabalham com seus alunos em sala de aula; nesse sentido, partimos para os temas da Educação em Ciências, verificando os textos elaborados.

Tendo em vista o viés de nossa pesquisa em relação à temática argumentação, trabalhamos com o Padrão de Argumento de Toulmin (2006), porém aliando-o a um plano conversacional e a um discurso situado, como discutido por Amossy (2007), de modo a agregar a este modelo outros elementos.

Retomamos também, para análise dos textos apresentados pelos sujeitos de nossa pesquisa, discussões e resultados de pesquisas na área de ensino de Física, Química e Biologia, as quais consideramos pertinentes de transferência para análise de argumentos abordando conteúdo das disciplinas pedagógicas e, portanto, que se aliam aos nossos objetivos. Na sessão seguinte, apresentamos uma discussão sobre esses aspectos, considerando os referenciais teóricos adotados nesta pesquisa.

\section{ARGUMENTAÇÃO E QUALIDADE DE ARGUMENTOS}

\subsection{Argumentação - Considerações fundamentais}

De acordo com van Eemeren et al. (1996), a argumentação pode se estruturar sob três diferentes formas: analítica, dialética e retórica. Em uma abordagem analítica, um argumento procede indutiva ou dedutivamente de um conjunto de premissas à conclusão. Argumentos analíticos pertencem ao domínio do raciocínio formal, o qual se interessa pela estrutura lógica dos argumentos, verificando se a conclusão surge logicamente de premissas dadas. De acordo com a teoria lógica, os argumentos incluem, por exemplo, implicações materiais, silogismos e falácias.

Raciocínios que não empregam a lógica formal são denominados de raciocínios informais. Eles consideram, portanto, as formas dialética e retórica de argumento. Os argumentos dialéticos são aqueles que ocorrem ao longo de um debate ou discussão e envolvem um raciocínio com premissas que não são evidentemente verdadeiras. Os 
argumentos retóricos, por sua vez, são de natureza oratória e compreendem técnicas empregadas por um orador para persuadir uma audiência. Diferentemente dos argumentos analíticos e dialéticos, em que a consideração de evidências que ancoram as conclusões é fundamental, os argumentos retóricos enfatizam antes o conhecimento de uma audiência sobre o tema em discussão.

A divisão discutida por van Eemeren et al. (1996), bem como a tradição dos estudos argumentativos remonta a Aristóteles e à sua definição de raciocínio, ou seja, a operação da razão como argumentação. Raciocinar, para Aristóteles, presumia saber extrair conclusões de proposições estabelecidas pela linguagem. Para este filósofo, havia dois modos básicos de raciocinar: a demonstração analítica, que parte de premissas verdadeiras e é exclusiva da lógica, ou raciocínio formal, como denominado por Toulmin (2006); e a argumentação dialética, que parte de premissas prováveis, das quais podem ser extraídas conclusões apenas verossímeis, representando uma forma diversa de raciocinar. Aristóteles examina como tais premissas podem ser usadas em um debate, em que há partes que aceitam e outras que se contrapõem a elas. Essa dicotomia proposta por Aristóteles distingue tradicionalmente um campo mais objetivo da argumentação, em que argumentos são sustentados por premissas lógicas (logos), e outro campo, no qual é aceitável a alteração de uma linha argumentativa racional para a inclusão de figuras poéticas ou juízos morais a fim de se conseguir a adesão de um público à tese que se deseja defender, englobando uma visão mais subjetiva da argumentação (VAN EEMEREN et al., 1996; VIEIRA, 2007).

Dentro da visão dialética de raciocínio de Aristóteles, encontram-se dois tipos de argumentos retóricos ou meios artificiais de persuasão': os argumentos éticos (ethos), os quais envolvem o caráter moral do locutor, cuja atuação provoca confiança ou não em seus ouvintes; e os patéticos (pathos), os quais se relacionam às paixões, como alegria, aflição, amizade ou ódio, por exemplo. O primeiro deles, o ethos, leva em conta uma forma de argumentar que deriva da condição social, dos hábitos e da moralidade do locutor e projeta uma imagem deste no sentido de convencer a plateia. Portanto, nessa perspectiva, o papel do auditório já é considerado, uma vez que este pode ser convencido em função de uma identidade de valores e opiniões com os do locutor. Nessa concepção de argumentação, presume-se um jogo intersubjetivo entre orador/locutor e auditório. Com relação ao pathos, Aristóteles considerou que as paixões alteram os juízos proferidos em relação ao mundo, de modo que, se o discurso toca os sentimentos, cria-se um vínculo intersubjetivo que se centra nos valores que permeiam o discurso.

Vieira (2007) salienta que, ao longo da tradição filosófica ocidental, as duas formas de argumentação propostas por Aristóteles não mereceram o mesmo status, de modo que, apenas recentemente, a partir da segunda metade do século XX, a dialética alcançou o estatuto de seriedade e consistência já destinado à analítica.

O modo de raciocinar por argumentação dialética acabou por se dividir em duas vertentes: a retórica e a dialética. A primeira preocupa-se em alcançar uma adesão do ouvinte, daí ser considerada como voltada para uma audiência, ou seja, a audiência é o mais importante fator a se considerar; enquanto que a segunda enfatiza a resolução de diferenças de opinião. Em uma análise dialética, o discurso argumentativo é reconstruído centrando-se nos aspectos relevantes para assegurar um balanço ou acordo entre diferentes pontos de vista.

Duschl (2008) considera que, na Ciência, ao longo do processo de elaboração e justificação de teorias, todas as três formas de argumentos são utilizadas, embora a analítica e a dialética, devido ao foco nas evidências, sejam mais requeridas e mais representativas da alta qualidade da argumentação científica. Jimènez-Aleixandre e Erduran (2008), por sua vez, consideram que, dos variados nuances e significados da argumentação apresentados na literatura, no mínimo dois são relevantes para o contexto argumentação como persuasão. As autoras consideram que essa distinção está associada 
aos dois tipos de textos discutidos por Myers (1990, apud JIMÈNEZ-ALEIXANDRE; ERDURAN, 2008): argumentos científicos, relacionados a evidências, e narrativas que funcionam para persuasão. A argumentação em tópicos científicos pode ser definida como a conexão entre asserções (ou conclusões) e dados, por meio de justificativas ou avaliações do conhecimento à luz de evidências, que podem ser empíricas ou teóricas. A argumentação como persuasão pode ser entendida como um conjunto de estratégias para convencer uma audiência, como explicitado em van Eemeren et al. (1999), de acordo com a tradição de Aristóteles.

A despeito da influência de Aristóteles no campo da argumentação, um movimento em direção ao rompimento da dicotomia retórica versus dialética vem sendo observado a partir dos trabalhos de Perelman e Olbrechts-Titeca (1992). Esses autores enfatizam o fato de que a argumentação sempre se desenvolve em função de um auditório. Van Eemeren e Grootendorst (2004), com sua teoria dialético-pragmática da argumentação, seguem essa linha, representando uma ruptura radical com tal dicotomia. Nessa perspectiva, considera-se que, ainda que o interlocutor não esteja presente, ele pode ser pressuposto pelo locutor. Outro aspecto que vale ser ressaltado, é o de que os estudos contemporâneos sobre argumentação incorporam a noção de dados empíricos (falados ou escritos) ampliando a noção primária de Aristóteles, a qual envolve premissas (fundamentalmente teóricas) e conclusão. (VIEIRA, 2007)

A concepção de que a argumentação sempre se volta a uma audiência pode ser relacionada à discussão de Bakhtin (2000) sobre o enunciado. Para este filósofo da linguagem, todo enunciado tem autor, expressão e, sobretudo, destinatário. Nesse sentido, enquanto o enunciado é elaborado, o locutor tende a determinar uma possível resposta de modo ativo, a presumi-la. Essa resposta presumida reflete-se no enunciado, constituindo sua estruturação. O locutor não perde de vista o fundo perceptivo sobre o qual a sua fala será recebida pelo destinatário, ou seja, o grau de informação que este tem da situação, seus conhecimentos especializados sobre a área de determinada comunicação cultural, suas opiniões, concepções, preconceitos, suas simpatias e antipatias, dentre outros aspectos. (SILVA, 2008)

Amossy (2005) discute a noção retórica de ethos levando em conta diferentes campos tais como a linguística, a semântica, a análise do discurso e teorias da argumentação contemporâneas. A autora considera que “(...) deliberadamente ou não, o locutor efetua em seu discurso uma apresentação de si" (AMOSSY, 2005, p. 1) para o outro. Nesse sentido, o ato de tomar a palavra já implica a construção de uma imagem do locutor, independentemente deste fazer o seu auto-retrato, detalhar suas qualidades ou falar explicitamente de si mesmo.

Van Eemeren e Grootendorst (2004) consideram a argumentação uma atividade verbal e social de raciocínio, desenvolvida por um locutor (falante ou escritor) cujo interesse é aumentar ou diminuir a aceitabilidade de um ponto de vista controverso por meio de uma série de proposições que visam justificar ou refutar o ponto de vista ante um julgamento racional. Jimènez-Aleixandre e Erduran (2008) discutem que tal definição contem em si as duas perspectivas da argumentação que enfatizam: justificação do conhecimento e persuasão, o que naturalmente explicita a proposta da teoria pragmática-dialética de argumentação proposta por van Eemeren e Grootendorst (idem) no tocante à superação da dicotomia entre argumentação analítica e argumentação retórica. Nesse sentido, torna-se compreensível que justificação do conhecimento e persuasão se aliam e podem ser percebidas em diferentes campos do conhecimento da ciência em que se instaura a argumentação.

A fim de analisarmos a qualidade dos argumentos dos sujeitos de nossa pesquisa, consideramos o Modelo de Argumento de Toulmin (1958/2006), bem como alguns aspectos apontados por diferentes autores em discussões e empregos deste modelo em suas pesquisas. Por focar na estrutura do argumento, tal modelo se adequou aos 
propósitos de nossa pesquisa e aos dados referentes à argumentação dos sujeitos, os quais compuseram-se de textos sobre questões da Educação em Ciências.

No sentido de aprofundar a discussão acerca da argumentação, nas sessões que seguem discorremos sobre o Padrão de Argumento de Toulmin e as relações entre argumentação e Análise do Discurso, como proposto por Amossy (2007).

\subsection{O Padrão de Argumento de Toulmin e a qualidade dos argumentos}

Considerando-se a atividade de análise sobre um argumento, uma das questões centrais na literatura sobre argumentação é como o discurso argumentativo pode ser reconstruído de modo que todos os seus aspectos estruturais relevantes possam ser destacados (VIEIRA, 2007). Nessa perspectiva, se insere o Padrão de Argumento de Toulmin (2006). Originado para estudos no campo jurídico, o padrão de argumento de Toulmin tornou-se bastante difundido em outros domínios, tais como Comunicação, Filosofia e Didática das Ciências. Segundo tal padrão, os elementos estruturais fundamentais de um argumento são: o dado (D), a conclusão (C) e a garantia de inferência (G). A estrutura básica, portanto, é: "a partir de um dado $D$, já que $G$, então $C$ " (Fig. 1). A conclusão (C) é a alegação cujos méritos procuramos estabelecer; o dado (D) são os fatos aos quais recorremos como fundamento para a alegação; e a garantia de inferência (G) estabelece as relações entre os dados e a conclusão. Para Toulmin, não há argumento sem garantia de inferência. Com relação a isso, várias pesquisas (KUHN, 1993; ERDURAN, 2008, por exemplo) consideram a possibilidade de garantia de inferência implícita quando ela não é expressa explicitamente na passagem dos dados à conclusão.

À estrutura básica, podem ser acrescentados qualificadores modais (Q), palavras ou frases que expressam o nível de certeza dos falantes. Eles indicam uma referência explícita ao grau de força que os dados conferem à conclusão. Da mesma forma, por meio de uma refutação $(R)$ é possível especificar em que condições a garantia não é suficiente para dar suporte à conclusão. Os refutadores, portanto, especificam em que condições a garantia não é válida. Além dos elementos já citados, a garantia de inferência, que apresenta um caráter hipotético, pode ser apoiada em um conhecimento mais amplo ou categórico, como um princípio, uma lei ou teoria. Esse elemento que dá suporte à garantia de inferência é denominado de apoio ou conhecimento de base (B).

Figura 1: Padrão de argumento de Toulmin

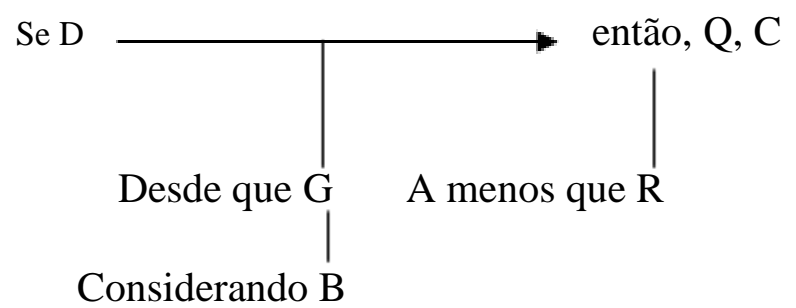

C

(Fonte: adaptado de 2006, p. 150)

0

nforme, apresentado, o foco do modelo proposto por Toulmin é a estrutura do argumento e não seu caráter dialogal; embora trabalhos focando as interações em sala de aula, cuja unidade de análise não é o indivíduo, o tenham utilizado com valiosas discussões. Como atestam Nascimento e Vieira (2009), o padrão promove certa facilidade ao processo de análise de situações argumentativas, principalmente pelo seu caráter normativo, que permite identificar o que é e o que não é um argumento. Todavia, apesar de bastante utilizado em pesquisas na área de Ensino de Ciências, há discussões 
contundentes sobre as suas fragilidades para as análises pretendidas, sobretudo por ele não considerar o aspecto contextual em que ocorrem os argumentos, não haver julgamento sobre a precisão e acurácia dos mesmos e focar no produto (o argumento) e não no processo argumentativo (a argumentação). Além disso, a amplitude de suas categorias, em várias situações, pode proporcionar certa dificuldade em sua aplicação aos dados, dificultando distinguir um elemento constituinte de outro. Isso tem gerado alterações em sua proposta original (ERDURAN, 2008; ERDURAN et al., 2004, ZOHAR; NEMET, 2002) ou, mesmo, a sua utilização como inspiração para originar outros esquemas analíticos (DUSCHL, 2008).

Zohar e Nemet (2002) modificaram o padrão de Toulmin (1958/2006) a fim de analisar a qualidade de argumentos escritos de alunos no contexto do ensino de genética humana. As autoras consideraram como argumentos fortes aqueles que apresentavam múltiplas justificativas (Garantias de inferência) para ancorar uma conclusão, as quais incorporavam fatos e conceitos relevantes e acurados. Argumentos fracos envolviam geralmente uma única justificativa ou justificativas não relevantes e, por fim, asserções apresentadas sem justificativas não foram consideradas argumentos.

Na metodologia proposta por Erduran et al. (2004), a qualidade de um argumento é verificada com base nas combinações dos elementos propostos no Modelo de Argumento de Toulmin (2006). Argumentos que se constituem em combinações com um maior número de elementos são considerados mais sofisticados que aqueles que apresentam apenas alguns poucos. Tendo em vista tal critério para qualificação dos argumentos, Sá, Kasseboehmer e Queiroz (2014) observaram como oportuno considerar também a frequência com que os elementos aparecem no argumento e não apenas a combinação entre eles. Isso possibilita discriminar argumentos compostos pelos mesmos elementos, mas que se diferenciam no número de vezes com que estes aparecem, sobretudo no tocante às garantias de inferência.

No trabalho desenvolvido por Sadler e Donnelly (2006), o qual se voltou para a argumentação de estudantes em torno de questões sócio científicas envolvendo engenharia genética, a qualidade dos argumentos foi verificada considerando-se a capacidade dos alunos em apresentar justificativas para as suas ideias, considerar as possibilidades de diferentes pontos de vista e desafiar uma fundamentação com uma contraposição.

Como discutido em Garcia-Mila et al. (2013), justamente por focar na estrutura dos argumentos, o modelo proposto por Toulmin (2006) permite verificar o nível de complexidade dos mesmos. Tendo em vista os trabalhos de Zohar e Nemet (2002) e Erduran (2004), dentre outros, os autores observam que a qualidade de um argumento pode ser verificada pela variedade e número dos elementos do modelo que este contempla. Nessa discussão, os autores consideram, ainda, a presença de contraargumentos e refutadores como um valioso indicativo da qualidade dos argumentos, baseando-se na discussão apresentada por Khun (1991). De acordo com esta autora (1991, apud GARCIA-MILA et al., 2013), contra-argumentos e refutadores são as habilidades mais complexas no discurso argumentativo. Quando os indivíduos levam em conta uma refutação, eles não apenas justificam a sua asserção, mas também procuram suas limitações, avançando no possível contra-argumento do parceiro e já, de certa forma, defendendo-se dele. O refutador é uma afirmação que responde ao contraargumento de um possível oponente por conter este contra-argumento. Além disso, para argumentar que a sua própria teoria é a mais correta, os indivíduos devem integrar em seu discurso teorias alternativas às suas, ou seja, considera-las em sua argumentação.

De acordo com Garcia-Mila et al. (2013), estratégias argumentativas correspondem à presença de alguns elementos específicos do discurso antes que outros (por exemplo, refutadores ou qualificadores) e implementação de estruturas complexas de 
argumentação, e o esquivar-se de perspectivas inconsistentes (errôneas ou pouco acuradas). Os "qualificadores" do raciocínio científico, por sua vez, correspondem de forma mais específica à presença de refutadores e contra-argumentos.

Nascimento e Vieira (2009) discutem sobre o papel do qualificador no modelo de Toulmin. Considerando os pesos dos elementos restritivos (refutadores) e justificatórios (dados e garantias de inferência), o qualificador é entendido como atenuante ou reforçador do status da conclusão alegada. Nesse sentido, os autores consideram que o qualificador na estrutura de um discurso contínuo, monologal, acaba por incluir um aspecto dialogal pois depende do sujeito e da comunidade de falantes que avaliam o argumento. Entendemos que a discussão apresentada por Nascimento e Vieira (idem) sobre o papel dos qualificadores em um argumento, bem como as de Garcia-Mila et al. (idem) sobre o papel dos refutadores, dentre outras na literatura, dirigem-se à percepção do argumento em um contexto em que se evidencia o papel do outro, o ouvinte ou debatedor, na comunicação.

\subsection{Argumentação e análise do discurso - aproximações}

Na perspectiva da análise do discurso, Amossy (2007) discute a importância deste ramo das ciências da linguagem levar em conta o discurso argumentativo. A discussão que a autora apresenta envolve um contraponto entre estudos da linguística e da análise do discurso. Amossy (idem) observa que, por ter penetrado nas ciências da linguagem principalmente por Ansconbre e Ducrot (1988), os quais defendem a argumentação como um fato de língua e não de discurso, a argumentação manteve-se afastada da análise do discurso, compactuando com uma tradição pragmático-semântica que ainda exerce autoridade no campo.

A "argumentação na língua" é percebida como um conjunto de proposições ou enunciados que objetivam chegar a uma conclusão, e não no sentido amplo de persuadir. Nessa perspectiva, busca-se entender os conectivos que interligam os enunciados fazendo com que estes últimos sejam percebidos em suas relações mútuas, com elementos que garantem o encadeamento entre eles. Há encadeamentos argumentativos na própria significação das palavras. Os encadeamentos aparecem, mais explicitamente, entre enunciados breves. (AMOSSY, 2006, 2007).

De acordo com a dicotomia entre argumentação retórica e argumentação linguística proposta por Ducrot, a retórica, tendo natureza extralinguística, não pode compreender as possibilidades de encadeamento argumentativo. $\mathrm{O}$ autor considera que o impacto de um dado discurso em um auditório não se deve aos processos linguageiros articulados pelo orador, mas à situação do orador e a legitimidade institucional conferida à sua fala, de modo que o ethos se coloca como privilegiado sobre o logos. A legitimidade do discurso relaciona-se à posição do locutor, e não à força do raciocínio, que confere à linguagem o seu poder. (idem)

A posição adotada pela teoria da argumentação no discurso é completamente contrária ao que se postula por Ducrot, pois considerando a retórica no sentido da arte de persuadir, esta cede espaço ao logos, em relação com o ethos e o pathos. No campo de análise do discurso, configuram-se os seguintes elementos para o entendimento da argumentação: O papel do público ou do interlocutor e o plano comunicacional, em que a dimensão discursiva, e consequentemente, a argumentativa, mostram-se indissociáveis do socioinstitucional. Nesse sentido, manifestam-se estratégias destinadas a conquistar a convicção ou modalidades de fala que tentam orientar maneiras de pensar, seja de forma deliberada ou espontânea (idem).

Considerar o Modelo de Argumento de Toulmin nessa perspectiva implica colocá-lo em um plano conversacional, na densidade de um discurso situado, sem os quais, tomado 
em si mesmo, torna-se um "esqueleto sem carne", como tantos outros esquemas analíticos. Como salienta Amossy:

\begin{abstract}
Entretanto, na perspectiva da argumentação no discurso, é preciso observar que os esquemas assim extraídos e descritos devem ser recolocados não somente num plano comunicacional, mas também na densidade de um discurso situado. Eles constituem formalizações que permitem, certamente, observar como o discurso antecipa um raciocínio que se quer convincente (ou como ele fracassa ao fazê-lo). Eles são, portanto, úteis, até mesmo indispensáveis. Mas tomados em si mesmos, eles são um esqueleto sem carne. (AMOSSY, 2007, p. 132)
\end{abstract}

\title{
3. METODOLOGIA
}

\subsection{Os sujeitos da pesquisa}

Participaram desta pesquisa, como sujeitos, alunos de mestrado (7) e graduação (17) de duas universidades públicas: uma da região Nordeste e outra da região Sudeste do país, sendo ao todo 24 sujeitos. Todos eles são ligados à Licenciatura em Química, com exceção de um que era licenciado em Física. Consideramos neste artigo, para uma discussão detalhada sobre a estrutura dos argumentos apresentados, apenas 4 (quatro), os quais são alunos de mestrado: dois da universidade do Sudeste (Alex e ísis) e dois da universidade do Nordeste (Júlia e Rita). A seleção desses sujeitos foi feita tendo-se em vista que eles apresentaram diferentes estruturas de argumentos, as quais melhor representam a diversidade encontrada no grupo de alunos do mestrado. Consideramos tal grupo em formação continuada, haja vista que os seus integrantes, em sua maioria, atuavam em sala de aula ao tempo em que cursavam o mestrado, no momento da coleta de dados.

\subsection{O questionário e sua aplicação}

As asserções do protocolo abordaram conteúdos relevantes e fundamentais da Educação em Ciências, sendo eles: Modelos de Ensino-Aprendizagem em Ensino de Ciências e Matemática e Natureza da Ciência. Conforme informamos, tais conteúdos estão previstos nas ementas de disciplinas ministradas em cada mestrado, as quais os sujeitos cursaram ou estavam cursando no momento da coleta de dados. Os textos dos alunos foram transcritos na íntegra e submetidos à análise de acordo com o modelo de Toulmin, considerando-se ainda a exibição de elementos retóricos da dimensão do ethos e do pathos, conforme discutido.

As asserções foram elaboradas de modo a instigar os alunos a argumentarem sobre seus pontos de vista, levando em conta aspectos que davam margem à discussão, por serem colocados de modo a explorar uma controvérsia. Outro aspecto das asserções que merece ser ressaltado é o de que elas simulam a fala de um professor a respeito de suas concepções relacionadas ao ensino de ciências, implicando possíveis procedimentos em sala de aula. Neste artigo, discutiremos a Asserção 1 do questionário, a qual envolve os modelos de ensino -aprendizagem.

O questionário foi enviado on-line para os mestrandos do Nordeste e aplicados em aula aos mestrandos do Sudeste. A questão será apresentada na sessão em que os resultados são discutidos. 
Os dados escritos dos alunos foram transcritos na íntegra e submetidos aos seguintes passos de análise: 1- Identificação dos elementos do Padrão de Argumento de Toulmin (Toulmin Argument Pattern - TAP) em cada texto. 2- Fragmentação dos textos, representação dos mesmos por meio do TAP e análise das relações entre os elementos do padrão. 3- Análise dos elementos justificatórios (dados e conhecimentos de base) e refutadores verificando os conhecimentos científicos levados em conta e o nível de apropriação destes na elaboração dos argumentos. 4- - Análise de elementos retóricos de cada argumento, além daqueles que podem integrar os elementos constituintes do próprio padrão de argumento de Toulmin, ou seja, elementos na dimensão do ethos e do pathos . 5- Contraste entre os diferentes argumentos de cada sujeito e com os dos demais sujeitos da pesquisa - Caracterização dos níveis de complexidade e qualidade dos argumentos e 6- Síntese das relações entre os argumentos verificados e os aspectos socioinstitucionais considerados ao longo da análise.

\section{RESULTADOS E DISCUSSÃO}

Iniciamos a discussão apresentando a asserção da questão 1:

“Como professor (a) da área de Ciências da Natureza (Química, Física ou Biologia) e por ter tido acesso a discussões sobre ensino-aprendizagem, incluindo alguns modelos já propostos pela comunidade acadêmica da área, procuro desenvolver minhas aulas buscando compreender as concepções prévias dos alunos, todavia sem a expectativa de que elas sejam substituídas pelas concepções científicas. Apesar de compreender a importância de o professor trabalhar a partir dos conhecimentos prévios dos alunos, considero que não seja recomendável e mesmo possível promover tal substituição, na perspectiva de uma mudança conceitual. Concepções, valores e crenças que os indivíduos compartilham em seu cotidiano não devem ser extintos ou substituídos na escolarização."

A asserção acima pode ser percebida, estruturalmente, como composta de duas partes. Uma relacionada à importância das ideias prévias dos alunos para o desenvolvimento do processo de ensino-aprendizagem e outra relacionada à manutenção (ou não) dessas ideias após tal processo. Nesse sentido, foi possível perceber nas respostas dos mestrandos argumentos para cada uma delas, normalmente sobrepostos. Recortamos, assim, 2 estruturas de argumento (argumento 1 e argumento 2), no mínimo, em cada resposta a esta questão.

Antes de passarmos aos textos dos alunos, tecemos algumas considerações sobre o conteúdo da asserção. Muitos aspectos podem ser trazidos para a discussão sobre esses dois modelos de ensino-aprendizagem que marcam a história da pesquisa e do ensino de ciências: desde seus pressupostos epistemológicos à sua adoção na pesquisa e no ensino e, ainda as discussões mais recentes sobre perfil conceitual que acrescentam novos elementos à proposta original (MORTIMER; EL-HANI, 2014). Entretanto, abordamos aqui apenas aqueles que melhor marcam o contraponto entre estes modelos.

Conforme amplamente discutido na literatura da área, o Modelo de Aprendizagem por Mudança Conceitual, instaurado na década de 1980, presumia, de acordo com os pressupostos construtivistas, um processo pelo qual os alunos transformariam ou substituiriam as suas crenças ou ideias espontâneas (concepções prévias ou esquemas alternativos) sobre fenômenos naturais, por outras ideias mais sofisticadas, aquelas cientificamente aceitas. Nessa perspectiva, Posner et $a l^{2}{ }^{2}$ (1982) identificaram quatro condições para que se desse a mudança conceitual, focando no aspecto cognitivo do aprendiz. De acordo com este modelo, de forte raiz piagetiana, as concepções prévias dos alunos devem ser bastante valorizadas pelo professor, pois o sujeito aprende a partir do que ele já sabe (MORTIMER, 2000). 
Em contraposição à proposta de Aprendizagem por Mudança Conceitual, Mortimer (2000) apresenta a noção de perfil conceitual, partindo da noção de perfil epistemológico proposta por Bachelard (1996). De acordo com a noção de perfil conceitual, um conceito pode ser abordado de diferentes formas em função dos compromissos filosóficos, bem como ontológicos e epistemológicos da abordagem, o que gera distintas zonas no perfil de um indivíduo para tal conceito. Nessa perspectiva, a aprendizagem de ciências corresponde à construção de novas zonas do perfil, superando-se os obstáculos epistemológicos presentes em zonas anteriores; todavia, a construção de concepções em uma zona científica do perfil não presume a extinção de zonas que contemplam ideias cotidianas ou saberes de outra natureza que não a científica, uma vez que tais saberes certamente serão utilizados em outros ambientes e contextos. Considerando-se o processo de ensino como uma mudança de perfil conceitual, torna-se possível também abordar conceitos em um nível mais complexo, sem referir-se a eles em outro mais elementar, uma vez que concepções científicas não são percebidas como um refinamento ou extensão de ideias do senso-comum, por exemplo. Por outro lado, lidar com as contradições que as preconcepções representam para a construção de ideias científicas pode ocorrer em qualquer momento do processo de ensino e não apenas no seu início.

No processo de ensino na perspectiva do perfil conceitual, cabe ao professor, ao tentar promover a construção do conceito em uma determinada zona, proporcionar a ajuda pedagógica necessária para a transposição dos obstáculos a essa construção. Nesse momento, a interação entre professor e alunos implica uma negociação de significados a fim de que estes incorporem elementos de uma nova cultura - a científica.

A noção de perfil conceitual surge na década de 1990 como modelo alternativo para a compreensão das ideias dos estudantes, sobretudo por apresentar possibilidades de compreensão acerca dos resultados oriundos do montante de pesquisas que evidenciavam a resistência das ideias prévias dos estudantes às mudanças pretendidas na perspectiva do Modelo de Aprendizagem por Mudança Conceitual.

Passamos, a seguir, à apresentação e análise dos argumentos elaborados pelos mestrandos. Ressaltamos que os textos foram transcritos sem alteração dos originais. Eles são apresentados aqui, se não integralmente, em seus trechos mais relevante para a discussão que desenvolvemos. Iniciamos com aqueles da Universidade do Sudeste.

Texto de "Isis"

Concordo em parte com essa afirmação. Apesar de atualmente não estar em sala de aula, já lecionei durante dois anos durante a Licenciatura em Física. Concordo que é importante que o professor utilize dos conhecimentos prévios dos alunos e suas concepções alternativas, porém a parte em que discordo é que alguns modelos científicos podem sim causar uma substituição do conhecimento prévio do aluno pelo conhecimento científico, abandonando completamente seus "conhecimentos prévios". Porém em alguns casos ocorre a formação de um perfil conceitual onde os dois conceitos coexistem e o aluno escolherá qual utilizar dependendo do contexto social em que ele convive no momento.

Ex: Os conceitos utilizados em sala de aula podem não ser expressos em um campo de futebol. Se levarmos para a Física, apesar de ele aprender em sala de aula que se ele chutar a bola com um ângulo $\Theta \geq 450$ ele terá maior altura e que se $\Theta<45^{\circ}$ o alcance será maior (claro que de forma gradativa) ele pode não usar em uma partida de futebol.

Alguns conceitos, se tomarmos uma posição construtivista, devem ser enculturados, visto que não constam no cotidiano do aluno e que se constam têm um significado deturpado.

O argumento 1 de Isis traz como conclusão a concepção de que (...) é importante que o professor utilize dos conhecimentos prévios dos alunos e suas concepções alternativas (...); todavia, tal conclusão aparece sem justificativas. Nesse sentido, ele não se constitui em um argumento propriamente dito, de acordo com o que discutimos. A concepção de 
que os conhecimentos prévios dos alunos são importantes no processo de aprendizagem e de que o professor, portanto, deve ter acesso a tais conhecimentos procurando compreendê-los, como informado na asserção, pode ser associado ao pressuposto construtivista, o qual considera que a aprendizagem ocorre a partir das concepções prévias do aprendiz. Isso não é explicitamente declarado pela aluna, constituindo-se em uma inferência nossa, tendo em vista a sua participação nas aulas em que tal tema foi abordado. Além disso, a valorização das ideias prévias dos alunos é um preceito que tem sido recorrente na literatura da Educação e Ensino de Ciências há algum tempo e que tem sido também incorporado no discurso da comunidade de professores.

Com relação a segunda parte da asserção, que se refere à manutenção (ou não) das concepções prévias dos alunos após o processo de ensino, temos um argumento (argumento 2) cuja conclusão pode ser percebida como constituída de duas situações de aprendizagem que se contrapõem entre si e que, portanto, podem ser percebidas como "refutadores" uma em relação à outra. Nesse sentido, temos um argumento composto por conclusão e refutador e, para este último, uma nova estrutura argumentativa em que aparecem, além do refutador em si (ou segunda conclusão), dado e conhecimento de base.

Ísis considera que, em certas situações, a mudança conceitual acontece, todavia, em outras ocorre a formação de um perfil conceitual. A ideia de mudança conceitual aparece na conclusão da aluna. Refutando tal conclusão, porém, ela apresenta a situação em que ocorre a formação de um perfil conceitual e, nesse sentido, oferece como dado um exemplo envolvendo uma situação cotidiana em que os conhecimentos da Física sobre ângulo, distância e velocidade podem ser compreendidos pelos estudantes, mas não serem utilizados no campo de futebol. O conhecimento de base associado a esta situação é o modelo de perfil conceitual, o qual ela explicitamente informa.

Percebemos, no texto de Ísis, uma estrutura de argumento em que são explícita e implicitamente apresentados conceitos que têm a função de assegurar as conclusões declaradas; ou seja, um dos elementos justificatórios do Modelo de Toulmin (conhecimentos de base) foi levado em conta para dar consistência às suas declarações. Não há, entretanto, distribuídos nesses elementos da estrutura argumentativa, informações sobre porque em alguns casos a mudança conceitual acontece e, em outros, forma-se um perfil conceitual.

É relevante verificar que, no caso do argumento 1, consideramos como dado (ou como fonte de dados) a afirmação da aluna sobre a sua experiência como professora durante a Licenciatura em Física. Ísis já havia participado como professora em um projeto de extensão e também do PIBID. Entendemos que ela busca reafirmar a ideia de que tem experiência (dados de sala de aula) a partir da qual pode afirmar sobre a importância dos conhecimentos prévios dos alunos no processo de ensino-aprendizagem.

Abaixo apresentamos esquemas para os argumentos de Ísis: 
Figura 2: Argumento 1 de Ísis

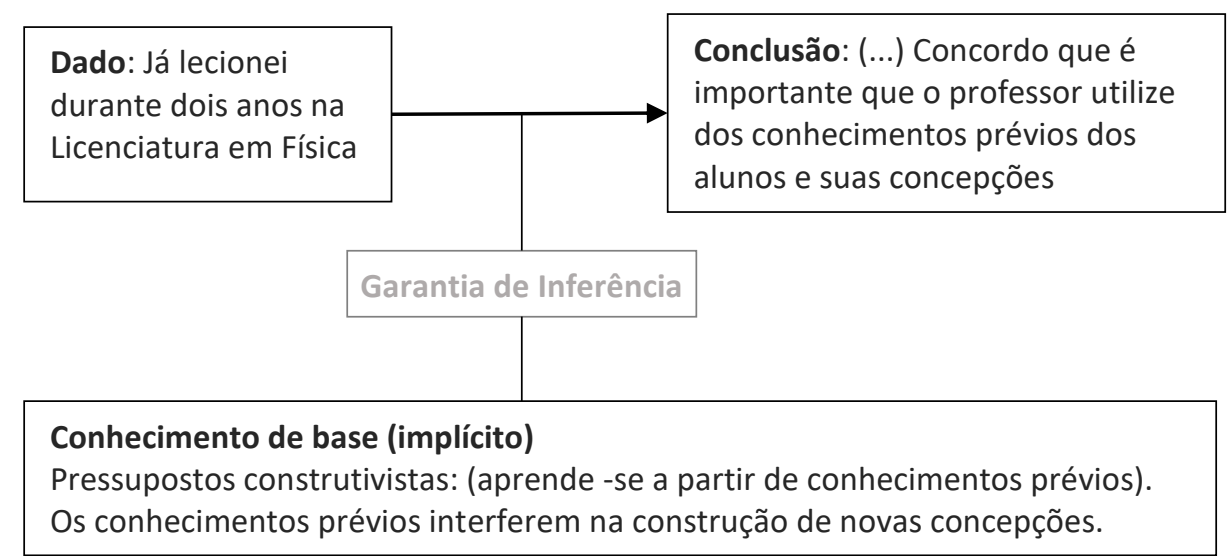

(Fonte: Os autores.)

Figura 3: Argumento 2 de Ísis

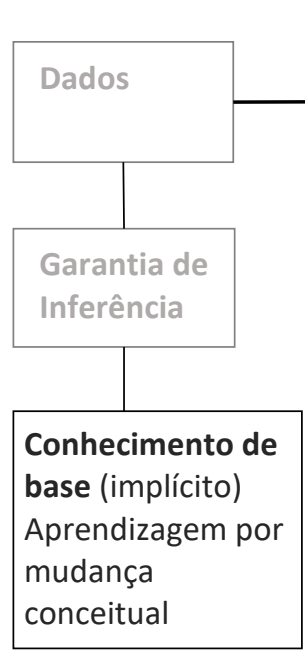

Página | 106

Conclusão 1: (...) alguns modelos científicos podem sim causar uma substituição do conhecimento prévio do aluno (...).

Dados para o refutador: Os conceitos utilizados em sala de aula podem não ser expressos em um campo de futebol. Se levarmos para a Física, apesar de ele aprender em sala de aula que se ele chutar a bola com um ângulo $\Theta \geq 45^{\circ}$ ele terá maior altura e que se $\Theta<45^{\circ}$ o alcance será maior (claro que de forma gradativa) ele pode não usar em uma partida de futebol
Refutador (Conclusão 2):

Porém, em alguns casos ocorre a formação de um perfil conceitual onde os dois conceitos coexistem e o aluno escolherá qual utilizar dependendo do contexto social em que ele convive

Conhecimento de base para o refutador:

Modelo de Perfil Conceitual (incluso do refutador)

(Fonte: Os autores.)

A afirmação de Ísis sobre sua experiência em sala de aula pode ser interpretada tendo em vista que o seu texto busca dialogar com o professor hipotético que faz suas declarações por meio das asserções propostas. Trata-se de um professor que, além de estar em sala de aula atuando, teve acesso aos temas discutidos na universidade. Tal professor foi "criado" por sua professora na disciplina do mestrado, a qual aplicou o protocolo de pesquisa a ela e a seu colega Alex. Em diálogo com tal professor (fictício) e, portanto, com a sua professora (real), Ísis informa que além do conhecimento acadêmico também tem alguma experiência em sala de aula. Esse elemento pode ser considerado na esfera do ethos numa dimensão retórica da argumentação. Nessa perspectiva, Ísis busca apresentar informações sobre si, certamente a fim de ser mais convincente à sua audiência ou à sua interlocutora, a professora e pesquisadora. Ter experiência em sala de aula parece dar uma base empírica para o professor falar de questões relacionadas a este ambiente e no seu caso, associando os conhecimentos tácitos aos acadêmicos. Além 
desse aspecto, a importância de apresentar informações sobre os conhecimentos trabalhados em sala de aula, ao longo da disciplina, pode ser percebida. Nesse sentido, aparecem dado e conhecimento de base correspondentes aos conceitos aí desenvolvidos.

Passemos ao texto de Alex:

Texto de "Alex"

As ideias prévias dos alunos, num processo de ensino aprendizagem, são de suma importância, e tida como essencial para determinado tópico/assunto por parte do professor, visto que tais ideias podem ou não estar mais próximas do científico, cabendo ao professor inferir sobre.

Acredito que nem toda ideia prévia é substituída integralmente, sempre ficando uma mescla das ideias iniciais dos alunos com os novos conceitos (científicos) agora incorporados.

Assim, na escolarização, os conceitos podem ser extintos ou substituídos, porém muitas dessas ideias prévias que os alunos trazem para a sala de aula sobre as ciências (Química, Física ou Biologia), muitas vezes têm influência da cultura, dogmas, dentre outros aspectos, relacionados às comunidades onde o aluno está inserido, como a instituição igreja, fazendo aqui uma exemplificação sobre um assunto bastante discutido na Biologia, que é o Criacionismo X Evolucionismo, mostrando um exemplo onde muitas vezes o aluno não deixa de lado as ideias iniciais advindas de instituições extra escola, que muitas vezes está relacionada à família, origem social, capital cultural etc.

Na sala de aula a cultura científica é absorvida de acordo com as interações entre os sujeitos (aluno-professor e aluno-aluno) e, como já dito anteriormente, os valores advindos de outras instituições onde o aluno se insere como igreja, família etc permeiam bastante os conceitos dos alunos. (...).

A aprendizagem por Mudança Conceitual, ancorada em Ausubel, Piaget presume que

O texto de Alex apresenta, para o argumento 1, conclusão com justificativa envolvendo um dado teórico e um conhecimento de base implícito. A tese de Alex para o argumento 1 assegura que as ideias prévias dos alunos (...) são de suma importância e tidas como essenciais por parte do professor, pois este precisa saber o quão próximas estas ideias estão das científicas, o que orientará o seu processo de ensino. A ideia repassada é a de que os professores precisam inferir sobre o que os alunos sabem sobre determinado tema para a partir de aí construir os conceitos científicos. Nesse sentido, tem-se como dado o seguinte: tais ideias ((as ideias prévias dos alunos)) podem ou não estar mais próximas do científico, cabendo ao professor inferir sobre. Ligando o dado teórico à conclusão encontra-se implícito o pressuposto construtivista de que se aprende a partir do que se conhece, semelhante ao que observamos no texto de Ísis.

No argumento 2, verificamos a presença de conclusão que traz em seu bojo o pressuposto do Modelo de Aprendizagem por Mudança Conceitual. Este é discutido por Alex no final de seu texto, reportando-se inclusive às condições propostas por Posner et al. (1982) para a ocorrência de tal mudança. A conclusão de Alex neste segundo argumento é: (...) na escolarização, os conceitos podem ser extintos ou substituídos.

Todavia, para Alex, nem toda aprendizagem pode ser entendida por meio deste modelo; nesse sentido, ele apresenta o refutador (ou conclusão 2) cuja ideia fundamental é a de que há certas concepções envolvendo valores e dogmas que se ligam à outras instituições das quais o aluno é membro, que não são facilmente ou totalmente alteradas no processo de escolarização. Nessa perspectiva, o Modelo de Aprendizagem por Mudança Conceitual pode ser considerado quando a aprendizagem não implica interferência em crenças e valores do aprendiz. Justificando o refutador, Alex coloca um dado teórico que compreende a discussão entre criacionismo e evolucionismo. Há subjacente e implícita no texto a garantia de inferência, a qual considera que os 
Vemos que, tanto o argumento 2 de Alex, quanto o de Ísis apresentam refutador para o qual se configura uma nova estrutura de argumento, compreendendo elementos justificatórios (dados, garantia de inferência e/ou conhecimento de base). Todavia, alguns contrapontos entre ambos os argumentos merecem ser discutidos. No argumento 2 de Ísis, o refutador (conclusão 2) já apresenta em si o conhecimento de base a que se relaciona, ou seja, a noção de perfil conceitual. Sobre isso, comentamos que no argumento de Ísis não se explora porque em alguns casos a mudança conceitual acontece e, em outros, forma-se um perfil. Esse aspecto é explicitado no argumento de Alex, quando ele informa que, quando se trata de conhecimentos que envolvem crenças, dogmas etc, estes não são facilmente ou mesmo nunca abandonados. Essa informação aparece mais de uma vez no texto, constituindo-se em uma garantia de inferência que liga os dados à conclusão 2 (o refutador), embora acabe imbricada em outros elementos constituintes do modelo de Toulmin. Tal garantia de inferência torna o argumento 2 de Alex mais equilibrado, estruturalmente, que o de Ísis. Por outro lado, Alex nada diz sobre o modelo que discute a convivência entre as concepções epistemologicamente diferentes em um mesmo indivíduo, ou seja, ele não se refere ao modelo de perfil conceitual ou outro referencial que ancore tal afirmação. Ao contrário, o aluno apresenta detalhes do Modelo de Mudança Conceitual, apresentando uma citação direta do texto de Posner et al. (1982).

Tanto no texto de Alex quanto no de Ísis, o refutador aparece precedido por "porém". Tal palavra, semelhante a outras que conectam os elementos constituintes do padrão, se configurou em um marcador textual importante em nossa análise.

A seguir passamos à análise dos textos dos alunos da universidade do Nordeste.

Texto de "Julia"

Concordo em partes. Quando nós tratamos dos processos de ensino e aprendizagem, devemos levar em consideração as concepções prévias dos alunos, a partir dela o professor pode entender o que o aluno concebe sobre determinado conceito e auxiliá-lo na construção mais elaborada deste (caso a apresentada pelo aluno se distancie do que é considerado cientificamente aceito). De acordo com Mortimer (2000) em sua teoria de perfil conceitual ele afirma que para um determinado conceito cria-se um perfil conceitual que é composto por zonas e cada zona representa uma maneira de explicar um determinado conceito, as interações com o meio favorecem a criação de zonas, pois o meio pode proporcionar novas explicações para o conceito. Nessa perspectiva não se substitui uma concepção prévia por uma científica, cria-se uma nova zona, ou seja, uma nova maneira de explicar um conceito, sem abandonar a maneira anterior. Ressalto que os valores e crenças, devem ser levados em consideração no processo de escolarização, por estes caracterizar uma cultura e um povo, mas também acredito que a escola traz consigo uma cultura própria e que esta pode causar mudanças internas no indivíduo $e$ gerar novas crenças e valores.

No seguinte trecho "[...] procuro desenvolver minhas aulas buscando compreender as concepções prévias dos alunos, todavia sem a expectativa de que elas sejam substituídas pelas concepções científicas", acredito que a ideias não são substituídas, porém de acordo com a teoria de Mortimer (2000) para perfil conceitual, (...).

A parte inicial do texto de Júlia apresenta um "argumento" (argumento1) que se assemelha aos de Ísis e Alex, ou seja, ela considera a importância das concepções prévias dos alunos, pois a partir delas é que o professor poderá se orientar melhor para condução de seu processo de instrução. Tem-se aqui, também implícito, o pressuposto construtivista ao qual temos nos referido. A partir daí, Júlia chega ao argumento 2, em que considera que as concepções prévias não são abandonadas, mas passarão a compor um perfil conceitual juntamente com as concepções científicas. Nesse sentido, temos, no argumento 2, conclusão e conhecimento de base, o qual corresponde ao modelo de perfil conceitual. Ao longo do texto, Júlia vai acrescentando novos aspectos para estes componentes (conclusão e conhecimento de base), ou seja, ela passa a ressaltar a ideia 
de que o fato de o aluno não abandonar as suas concepções prévias não significa que não tenha passado por mudanças ao longo do processo de escolarização. Nessa perspectiva, ela acrescenta:

Conclusão: (...) mas a escola (...) pode causar mudanças internas no indivíduo e gerar novas crenças e valores.

Conhecimento de base: a escola traz consigo uma cultura própria (...)

Conclusão: (...) todavia o sujeito não será como antes.

Conhecimento de base: (...)conhecimento científico possibilitará uma nova leitura do fenômeno estudado.

É interessante verificar que, para colocar esses novos aspectos em sua conclusão e conhecimento de base, ela recorre aos termos, "mas" ou "todavia"; entretanto, tais palavras não se prestam a acrescentar refutadores à sua conclusão, como nos casos de Alex e Ísis. A sua intenção é apenas passar a introduzir um reforço a aspectos que podem não ficar evidentes à primeira vista em seu texto. Outro fato que merece destaque é o de que ela toma como conhecimento de base apenas a ideia de perfil conceitual, ou seja, Júlia não vê a possibilidade de aprendizagem como mudança conceitual como nos casos de Ísis e Alex, nem contrapõe o modelo de perfil conceitual ao de Aprendizagem por Mudança Conceitual. Nesse sentido, os refutadores à sua conclusão não aparecem. Vendo desse prisma, consideramos que, apesar de o texto de Júlia apresentar elementos que respaldam bem a sua conclusão, não se antecipa a possíveis contra-argumentos, explicitamente; não se defende, por exemplo, de asserções que considerem possibilidades de mudança conceitual. Isso é vislumbrado nos textos de Ísis e principalmente no de Alex.

De toda forma, é notável que em todos os três textos vistos até aqui, os locutores recorrem explicitamente a conhecimentos científicos que atuam como conhecimentos de base, o que do ponto de vista da argumentação científica é recomendado. Além disso, apresentam elementos fundamentais à uma boa estrutura argumentativa de acordo com o Modelo de Argumento de Toulmin.

Abaixo encontram-se as estruturas de argumento de Júlia. 


\section{Dado teórico:}

(...) a partir delas ((as concepções prévias)) o professor pode entender o que o aluno concebe sobre determinado conceito e auxiliá-lo na construção mais elaborada deste (caso a apresentada pelo aluno se distancie do que é considerado cientificamente aceito).

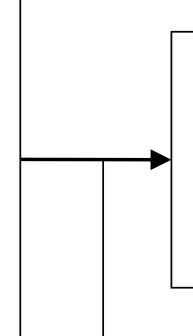

\section{Conclusão:}

(...) devemos levar em consideração as concepções prévias dos alunos (...)

\section{Argumento 1b}

\section{Garantia de Inferência}

\section{Conhecimento de base}

((Pressuposto construtivista - o aluno constrói ideias a partir das anteriores)).

\section{Dado (teórico)}

(...) ((valores e crenças)) caracterizarem uma cultura e um povo.

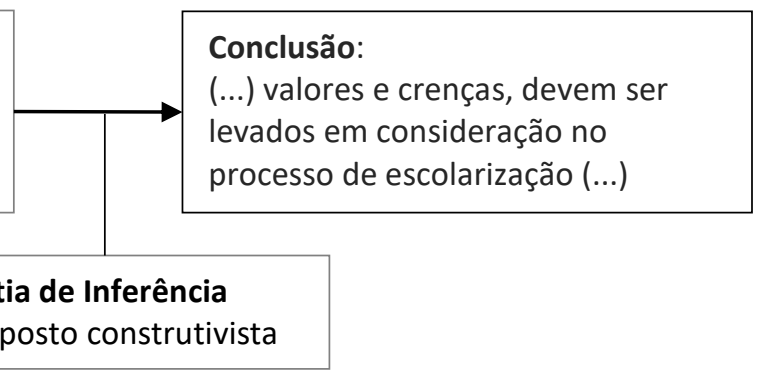

(Fonte: Os autores.)

Figura 7 - Argumento 2 de Júlia

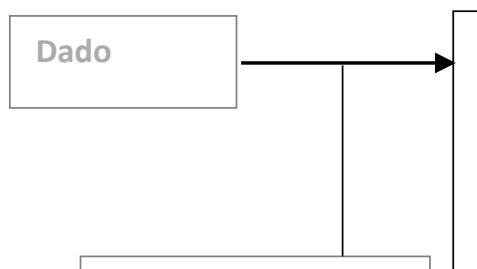

Garantia de Inferência

Conclusão: (...) não se substitui uma concepção prévia por uma científica, cria-se uma nova zona, ou seja, uma nova maneira de explicar um conceito, sem abandonar a maneira anterior. (...) todavia o sujeito não será como antes(...) pois o conhecimento científico possibilitará uma nova leitura do fenômeno estudado. (...)a escola (...) pode causar mudanças internas no indivíduo e gerar novas crenças e valores.

\section{Conhecimento de base}

(...) para um determinado conceito cria-se um perfil conceitual que é composto por zonas e cada zona representa uma maneira de explicar um determinado conceito, as interações com o meio favorecem a criação de zonas, pois o meio pode proporcionar novas explicações para o conceito. (Modelo de Perfil Conceitual).

(...) a escola traz consigo uma cultura própria (...) 
Vejamos, agora, o texto de Rita.

Texto de "Rita"

Não existe educação para o povo sem levar em conta a cultura do povo, o aluno possui um conhecimento prévio que vem da sua vivência cotidiana, da cultura de seu povo, tendo em vista que a educação não ocorre somente na escola, mas em todo espaço onde ocorre interação social as pessoas educam-se entre si; o que deve-se buscar é que o aluno se aproprie da linguagem e do conhecimento cientifico, mas sem romper com a cultura popular, pois isso além de não ser efetivo, seria uma violência se de fato ocorresse. $O$ aluno deve ser capaz de enxergar a ciência como sendo parte de sua vida cotidiana a fim de ser alfabetizado cientificamente, penso que não deve haver substituição e sim incorporação e apropriação. Não se deve chegar para uma pessoa e dizer a ela que tudo que ela viveu e aprendeu com seu povo é mentira e deve ser esquecido, isso é a mesma violência a que foram submetidos os índios pelos missionários.

O texto de Rita argumenta em favor de uma educação que não desconsidere as concepções prévias dos alunos, uma vez que estas fazem parte de sua cultura e desvalorizá-la seria uma violência. Todavia, a defesa pelo respeito às concepções prévias não envereda por teorias que analisam as relações entre os conhecimentos cotidiano e científico, tendo-se em vista, dentre outros, os aportes da psicologia e epistemologia da ciência, como é o caso dos modelos de Aprendizagem por Mudança Conceitual e Perfil Conceitual. Tais modelos apresentam uma profunda discussão sobre as relações entre as concepções prévias e as científicas e o processo de construção de novas ideias no ambiente escolar. $\mathrm{O}$ argumento de valorização das concepções prévias no texto de Rita se ancora no pressuposto mais amplo de respeito às culturas e, nesse aspecto há relação com o Modelo de Perfil Conceitual, todavia ela não se refere a ele. O que pode ocorrer no encontro dessas culturas e a construção de novas ideias pelos alunos é pouco explorado. Há, todavia, uma alusão a tal processo, quando Rita observa que romper com a cultura popular "(...) além de não ser efetivo, seria uma violência se de fato ocorresse"; ou seja, romper com a cultura popular é algo impossível e investir nisso não resultaria em êxito efetivamente. Nessa perspectiva, Rita considera que o aluno deve incorporar a cultura científica e consequentemente a sua linguagem sem, todavia, abandonar a sua cultura, a cultura popular.

A ideia de que a incorporação ou apropriação das concepções científicas não presume o abandono das concepções prévias ou alternativas encontra-se na base da proposta de perfil conceitual. Tal modelo considera possível a convivência entre concepções epistemologicamente diferentes, as quais poderão ser utilizadas em distintos contextos. Todavia, Rita não recorre aos termos "concepções alternativas" ou "cotidianas", os quais são muito recorrentes nas apresentações dos modelos de Aprendizagem por Mudança Conceitual e Perfil Conceitual. Ao contrário, Rita fala de cultura popular, cultura cotidiana, reportando-se inclusive à educação jesuítica em nosso país e América Latina, uma situação de nítida opressão de uma cultura por outra que a esta se impõe, como expressão do propósito de dominação dos europeus aos povos de suas colônias. Há em seu texto fortes marcas de um referencial que se volta para a discussão sobre a educação para o povo, uma educação popular. Isso pode ser melhor inferido se levarmos em conta que a dissertação de Rita teve como suporte o referencial de Paulo Freire, associado ao ensino de CTS.

Do ponto de vista estrutural, percebemos que a ideia de que as concepções prévias não devem ser desconsideradas no processo de ensino aprendizagem é um pressuposto, aparecendo no argumento na forma de dado teórico e, nesse sentido, ela não se presta à defesa, ao contrário, ancora as conclusões para o que temos aqui considerado como argumento 2, qual seja: as concepções prévias dos alunos não devem ser descartadas no processo de aprendizagem. Nessa perspectiva, temos como conhecimento de base de 
conteúdo, ou seja, com relação à importância da valorização das concepções prévias dos alunos no processo de aprendizagem.

A fim de defender a ideia de que a cultura do aluno não deve ou, mesmo, não pode ser substituída pela científica, Rita observa o quão absurdo é colocar para uma pessoa que o que ela aprendeu em outras esferas da sociedade deve ser esquecido. Ela faz uma analogia entre o ensino nessa perspectiva e o processo de colonização indígena e isso pode ser entendido como um elemento do pathos, na dimensão oratória do argumento. Atualmente, dificilmente alguém discordaria de que o processo de colonização ao qual os índios foram submetidos, acima de tudo, fere a dignidade humana. Nesse sentido, tem-se um apelo a não se repetir algo semelhante com nossos alunos em nossas salas de aula, ou seja, eles não devem ser feridos em sua dignidade pelo ataque a sua cultura e a das comunidades as quais pertence. Nessa perspectiva, também o argumento de Rita se diferencia dos anteriores, pois há um elemento forte na dimensão da oratória; por outro lado, semelhantemente ao argumento de Júlia, não apresenta refutadores que possam contemplar outros pontos de vista e, portanto, se adiantar na defesa diante de contraargumentos, relacionados às possibilidades de abandono de concepções prévias.

Vejamos a estrutura do argumento de Rita

Figura 8 - Argumento 2 de Rita (envolvendo o argumento 1)

\section{Dado teórico:}

(...) o aluno possui um conhecimento prévio que vem da sua vivencia cotidiana, da cultura de seu povo, tendo em vista que a educação não ocorre somente na escola, mas em todo espaço onde ocorre interação social as pessoas educam-se entre si.

\section{Conclusão:}

(...) (...) o que deve-se buscar é que o aluno se aproprie da linguagem e do conhecimento cientifico, mas sem romper com a cultura popular, pois isso além de não ser efetivo, seria uma violência se de fato ocorresse.

\section{Garantia de Inferência}

\section{Conhecimento de base}

(Pressupostos) O respeito à cultura popular e a outras culturas que não sejam a científica.

A ideia de alfabetização científica. "O aluno deve ser capaz de enxergar a ciência como sendo parte de sua vida cotidiana a fim de ser alfabetizado cientificamente. " A educação não ocorre apenas na escola.

(Fonte: Os autores.)

Diante da discussão que apresentamos podemos perceber diferentes estruturas de argumento, as quais podem ser caracterizadas em sua qualidade, tendo em vista o modelo analítico que consideramos. Os argumentos de Ísis e Alex apresentaram estruturas que chegavam a incluir refutadores, além de dados, conclusões e conhecimentos de base. Os refutadores, conforme discutimos, podem ser percebidos como forma de o locutor se adiantar a contra-argumentos, antecipando-os em seu próprio discurso. Os argumentos destes mestrandos levaram em conta os modelos de Aprendizagem por Mudança Conceitual e/ou Perfil Conceitual, considerando como ambos podem lidar com diferentes situações do processo de aprendizagem dos alunos. Nessa 
reciprocamente. Ísis e Alex recorrem explicitamente a teóricos para justificar os seus pontos de vista.

Os argumentos de Júlia apresentaram estruturas em que aparecem, de forma explícita, dados teóricos, conclusões e conhecimento de base. A mestranda levou em conta o Modelo de Perfil Conceitual, considerando como por meio deste é possível explicar a convivência entre concepções epistemologicamente diferentes após o processo de ensino-aprendizagem. Ela não contrapõe tal modelo ao Modelo de Aprendizagem por Mudança Conceitual, da forma como Ísis e Alex fizeram. Do modo como argumentou, pode-se supor que não considerou necessário outro modelo para descrever o processo de ensino-aprendizagem que ocorre em salas de aula de ciências.

Os argumentos de Ísis, Alex e Júlia podem ser percebidos como estruturas argumentativas que têm semelhanças no sentido de que apresentam elementos fundamentais do Modelo de Toulmin, trazendo conhecimentos de base para ancorar suas conclusões. Todavia, além dos refutadores, Ísis e Alex trouxeram ainda dados empíricos que deram maior concretude às conclusões alcançadas. Ísis apresentou o exemplo da percepção do ângulo com que a bola pode ser chutada em um campo de futebol. Alex considerou a relação criacionismo versus evolucionismo. Em todos os argumentos desses três mestrandos, todavia, pudemos verificar a explicitação dos conhecimentos de base, ou seja, dos referenciais teóricos aos quais se reportaram para dar sustento às suas conclusões, o que se torna fundamental na perspectiva da argumentação científica.

O argumento de Rita, por sua vez, envolveu basicamente dados teóricos e conclusões. Há princípios que podem ser inferidos em seu texto e percebidos como conhecimentos de base, à semelhança do que aconteceu em alguns dos argumentos dos três primeiros mestrandos considerados. O que chama atenção no texto de Rita é a força que o elemento da phatos lhe confere. Rita não citou explicitamente o modelo de Aprendizagem por Mudança Conceitual, o modelo de Perfil Conceitual, a perspectiva pluriculturalista de Cobern e Loving (2000) ou mesmo a pedagogia de Paulo Freire, por exemplo. Rita apresentou pressupostos que ancoravam sua conclusão sem se referir a títulos ou teóricos. Nessa perspectiva podemos considerar que o investimento em um elemento da dimensão do pathos no argumento de Rita toma lugar de elementos constitutivos do esquema da argumentação analítica que consideramos, na dimensão do logos.

A discussão que aqui apresentamos envolve os argumentos elaborados por quatro professores, todos eles mestrandos em ensino de ciências e tendo alguma experiência em sala de aula. Os argumentos por eles elaborados, tendo-se em vista principalmente a segunda parte da asserção proposta para reflexão, a qual considerava o que ocorria com as concepções prévias dos alunos no processo de ensino-aprendizagem, apresentou aspectos convergentes e divergentes entre si. Os argumentos apresentados por Ísis, Alex e Júlia, trouxeram suas conclusões ancoradas em conhecimentos de base explicitamente declarados, os quais corresponderam a referenciais teóricos dispostos na literatura da área de Educação em Ciências, o que é requerido do ponto de vista da argumentação científica. Tanto Ísis quanto Alex, entretanto, diferentemente de Júlia, apresentaram refutador para a conclusão que declararam, o qual pode ser percebido como uma segunda conclusão, correspondente a uma nova estrutura argumentativa. Nesse sentido, eles apresentaram elementos que apontavam reciprocamente "limites" em suas asserções conclusivas, adiantando-se a possíveis contra-argumentos. Dessa forma, expressaram situações em que as concepções prévias podem permanecer ou serem abandonadas ao longo do processo de ensino. A possibilidade de abandono das concepções prévias não é discutida por Júlia.

Os argumentos de Ísis e Alex, diferentemente do de Júlia, também apresentaram dados empíricos (para os refutadores), os quais correspondem a exemplos de situações concretas de ensino-aprendizagem. Esses aspectos nos fazem considerar os argumentos desses dois sujeitos um pouco mais amplos e consistentes que os de Júlia, sobretudo por 
levarem em conta diferentes pontos de vista ao longo da própria argumentação. Os exemplos de situações concretas de sala de aula, colaboram ainda para o poder de persuasão de seus argumentos. Os argumentos apresentados por esses três sujeitos, todavia, têm em comum o fato de esquivarem-se de perspectivas inconsistentes (errôneas ou pouco acuradas), ao menos no nível de elaboração conceitual requerido na pesquisa, pois todos eles apresentam concepções que, de alguma forma, ancoram-se adequadamente nos referenciais dos modelos de ensino levados em conta no enunciado proposto para discussão.

As representações das estruturas dos argumentos de Ísis e Alex nitidamente expressam as suas estratégias argumentativas: explicitam diferentes possibilidades explicativas, cujas conclusões são "refutadores" entre si, apresentam conhecimento de base e dados empíricos. Júlia, por sua vez, investiu mais na apresentação do conhecimento de base que ancorou a sua conclusão.

$\mathrm{O}$ argumento de Rita diferencia-se dos demais em alguns aspectos relevantes, sendo que, o que chama mais atenção é o seu investimento na dimensão do phatos, na perspectiva de argumentação retórica. Para isso, ela recorre a uma analogia entre a educação que despreza as concepções prévias dos alunos e a educação dos colonizadores sobre os colonizados. Vale ressaltar que esse investimento vem acompanhado de uma diminuição na discussão dos referenciais que ancoram a sua conclusão, comparado ao que se vê nos argumentos dos demais. A argumentação retórica foi historicamente relegada frente a analítica e a dialética, no plano da conversação científica, sobretudo por não focar na relação entre premissas e conclusão; todavia, tal dimensão, explícita ou implicitamente, permeia os argumentos científicos. A consciência desta dimensão argumentativa em relação ao logos certamente favorece a construção de argumentos. Não fica claro, todavia, se Rita não se sentiu segura para explorar mais os referenciais que ancoraram a sua conclusão ou se, realmente, não percebeu isso como necessário. Enfim, o que Rita apresenta traduz-se, estruturalmente, como um argumento menos elaborado que o dos demais aqui discutidos, sobretudo por não contemplar uma discussão sobre a relação entre as concepções prévias dos alunos e as novas ideias trabalhadas na escola.

\section{CONSIDERAÇÕES FINAIS}

A pesquisa que apresentamos neste artigo parte da concepção de que a instauração de práticas argumentativas em salas de aula de ciências depende fundamentalmente da habilidade dos professores em argumentar e fomentar a argumentação de seus alunos. A pesquisa voltada para a argumentação na formação e prática de professores de ciências, no entanto, ainda é recente, configurando-se, assim, um vasto campo a ser percorrido. Dentre as várias possibilidades de investigação nesse campo, consideramos relevante voltarmos atenção para as habilidades de argumentação de professores em relação a distintos temas associados à sua formação profissional. Nesse sentido, partimos para os temas da Educação em Ciências, verificando os textos elaborados por um grupo de professores em formação, tratando de aspectos sobre os quais eles tinham conhecimento formal, uma vez que o conhecimento do conteúdo abordado é fundamental para que se possa desenvolver um discurso argumentativo. Isso nos possibilitou verificar os entendimentos desses professores sobre argumentação, bem como as suas habilidades de elaboração de argumentos, quando solicitados a desenvolvê-los.

Compreender como os professores argumentam nos parece fundamental para que se discuta as possibilidades de instauração de práticas argumentativas em salas de aula de ciências. Trata-se de compreender as habilidades argumentativas dos professores em distintos contextos relativos à sua atuação, o que ao nosso ver amplia a discussão sobre a argumentação na formação de professores. Afinal, como se torna possível professores apresentarem argumentos consistentes e convincentes aos seus alunos, bem como fomentar a argumentação por parte destes se eles carecerem de boas estratégias 
argumentativas? Nessa perspectiva, é que voltamos nosso olhar para as estratégias argumentativas e a qualidade dos argumentos dos professores investigados.

Argumentar, em linhas gerias, significa justificar pontos de vista e persuadir. Ao longo de nossa vida, em distintas situações, argumentamos, e isso não é diferente para os professores aqui investigados, sobretudo no ambiente acadêmico e de sala de aula. Todavia, a elaboração de bons argumentos exige mais que uma percepção superficial ou intuitiva de argumentação. Exige uma compreensão de elementos fundamentais que devem compor estruturalmente um argumento, bem como das relações que tais elementos mantêm entre si. Além disso, uma boa articulação na dimensão retórica certamente favorece a persuasão.

Considerando os textos investigados, percebemos que os argumentos de Ísis e Alex apresentaram mais elementos que o dos demais, explicitando um investimento mais articulado na justificação de seus pontos de vista. Foge, todavia, ao escopo desse trabalho, tendo em vista os dados analisados, inferir consistentemente nas habilidades argumentativas desses professores em suas salas de aula. Por outro lado, é possível considerar que quanto mais elementos os professores conseguem agregar em sua estrutura argumentativa mais chances ele terá de apresentar bons argumentos em suas salas de aula e promover uma melhor argumentação de seus alunos. Nesse sentido, enfatizamos a importância de investir na análise dos argumentos de professores de ciências. Consideramos que o investimento na formação de professores sobre argumentação implica o entendimento desses professores acerca não apenas das especificidades características da argumentação na ciência, mas, antes disso, uma compreensão mais ampla de argumentação envolvendo elementos que são fundamentais em um discurso argumentativo em diferentes campos do conhecimento. Isso proporcionará ao professor elaborar argumentos consistentes para os seus alunos ao longo de suas aulas, bem como desenvolver estratégias didáticas voltadas para instigar a argumentação por parte de seus alunos, conduzindo-os à construção de melhores argumentos.

Os resultados discutidos neste artigo explicitaram argumentos com estruturas que, embora semelhantes em aspectos fundamentais, apresentam diferenças que expressam distintas formas de persuasão de uma audiência, tanto na dimensão dialética, quanto retórica do argumento. Isso expressa diferentes estratégias argumentativas. Entendemos que a metodologia analítica que adotamos pode avançar no sentido da associação dessas dimensões tendo em vista o Modelo de Argumento de Toulmin, na análise de dados orais e escritos de professores de ciências. 


\title{
Arguments of chemistry and physics teachers on teaching models: structural, dialectical and rhetorical aspects
}

\begin{abstract}
In this paper, we present a discussion about the structure and quality of the arguments elaborated by Chemistry and Physics teachers on subjects of Science Education. The protocol for obtaining the research data corresponded to assertions on which the research subjects had to express their points of view, justifying them. The written data were analyzed in according to Toulmin's Argument Pattern (2006), but re-placed in the density of a situated discourse (AMOSSY, 2007). The arguments produced were compared to each other and characterized in their quality regarding a dialectical structural as well as rhetorical aspects. In addition to a basic argument structure, were found arguments with refutators, which originated another argumentative structure with detailed data presentations and background knowledge. We also verified elements that could be perceived as characteristic of the dimension of pathos and ethos, from the point of view of argumentation as persuasion.
\end{abstract}

KEYWORDS: Arguments. Characteristics and quality of arguments. Science education. 
1 Os meios artificiais de persuasão para Arisóteles são aqueles que dependem das habilidades do falante sendo divididos em três tipos ou categorias: além do ethos e do pathos, o logos. Esta última é considerada argumentativa, enquanto que as duas primeiras são não-argumentativas. Quando o falante faz uso de logos, a argumentação é alcançada por meio de argumentos. O logos envolve silogismos retóricos dedutivos ou indutivos como entimemas e exemplos.

2 Para Posner et al. (1982), as quatro condições para que se desse a mudança conceitual seriam: o aluno deve sentir-se insatisfeito com a sua concepção prévia, a fim de que possa alterá-la; a nova ideia ou concepção cientificamente "correta" deve ser inteligível para ele; a nova ideia deve ser plausível e, enfim, a nova ideia deveria ser frutífera, permitindo-Ihe a ampliação do seu campo de conhecimento.

\section{REFERÊNCIAS}

AMOSSY, R. Argumentação e análise do discurso: perspectivas teóricas e recortes disciplinares. Tradução de Eduardo Lopes Pires e Moisés Olímpio Ferreira. Revista Eletrônica de Estudos Integrados em Discurso e Argumentação. Ilhéus. n. 1, p. 129-144, nov., 2011.

O lugar da argumentação na análise do discurso: abordagens e desafios contemporâneos. Filologia e linguística portuguesa. n. 9, p. 121-146, 2007.

Introdução: da noção retórica de ethos à análise do discurso. In: (Org.).

Imagens de si no discurso: a construção do ethos. Trad. Dilson F.da Cruz, Fabiana Komesu e Sírio Possenti. São Paulo: Contexto, 2005, p.9-28.

ANSCOMBRE, J. DUCROT, O. L'Argumentation dans la langue. Liège: Mardaga, 1988.

BACHELARD, G. A formação do espírito científico. Rio de Janeiro: Contraponto, 1996.

BAKHTIN, M.M. Estética da criação verbal. Trad. Maria Ermantina Galvão. 3. ed. São Paulo: Martins Fontes, 2000.

COBERN, W. W.; LOVING, C. C. Defining science in a multicultural world: implications for science education. Science Education, v. 85, n. 1, p. 50-67, 2001.

DUSCHL, R. Quality Argumentation and Epistemic Criteria. In: ERDURAN, S.; JIMÉNEZALEIXANDRE, M. P. (Ed.). Argumentation in Science Education: Perspectives from Classroom-Based Research. Dordrecht: Springer, 2008. p. 159-178.

EEMEREN, F. H. van; GROOTENDORST, R. Development in argumentation theory. In: 
EEMEREN, F. H. van; GROOTENDORST, R.; HENKEMANS, F. S.; BLAIR, J. A.; JOHNSON, R. H.; KRABBE, E.C.W.; PLANTIN, C.; WALTON, D. N.; WILLARD, C. A.; WOODS, J; ZAREFSKY, $D$. Fundamentals of argumentation theory: $A$ handbook of historical backgrounds and contemporary developments. Mahwah, N.J.: Lawrence Erlbaum, 1996.

ERDURAN, S. Methodological foundations in the study of argumentation in science classrooms. In: ERDURAN, S.; JIMÉNEZ-ALEIXANDRE, M. P. (Eds.). Argumentation in science education: Perspectives from classroom-based research. Dordrecht: Springer, 2008, p. 47-69.

.; SIMON, S.; OSBORNE, J. TAPping into argumentation: developments in the application of Toulmin's argument pattern for studying science discourse. Science Education, Hoboken, v. 88, n. 6, p. 915-933, 2004.

GARCIA-MILA, M.; GILABERT, S.; ERDURAN, S.; FELT, M. The Effect of Argumentative Task Goal on the Quality of Argumentative Discourse. Science Education, v. 97, n. 4, p. 497523, 2013.

JIMÉNEZ-ALEIXANDRE, M. P.; ERDURAN, S. Argumentation in Science Education: an overview. In: ERDURAN, S.; JIMÉNEZ-ALEIXANDRE, M. P. (Ed.). Argumentation in Science Education: Perspectives from Classroom-Based Research. Dordrecht: Springer, 2008. p. 327.

JIMÉNEZ-ALEIXANDRE, M. P; RODRIGUES, A. B; DUSCHL, R. “Doing the Lesson" or "Doing Science": Argument in High School Genetics. Science Education, v. 84, n. 1, p. 757-792, 2000. 55

KELLY, G. J.; REGEV, J.; PROTHERO, W. Analysis of Line of Reasoning in Written Argumentation. In: ERDURAN, S.; JIMÉNEZ-ALEIXANDRE, M. P. (Ed.). Argumentation in Science Education: Perspectives from Classroom-Based Research. Dordrecht: Springer, 2008. p. 137-158.

KELLY, G.; DUSCHL, R. A. Toward a research agenda for epistemological studies in science education. In: National Association for Research in Science Teaching, 2002, New Orleans. Proceedings of the National Association for Research in Science Teaching. New Orleans: LA, abr., 2002. p. 1-51.

KUHN, D. Science as Argument: Implications for Teaching and Learning Science Thinking. Science Education, v. 77, n. 3, p. 319-337, 1993.

MORTIMER, E. F. Linguagem e formação de conceitos no ensino de ciências. Belo Horizonte: UFMG, 2000. (Aprender). 
MYERS, G. Writing biology: texts in the social construction of scientific knowledge. Madison, WI: The University of Wisconsin Press, 1990.

NASCIMENTO, S. S; VIEIRA, R. D. A argumentação em sala de aula de física: limites e possibilidades de aplicação do padrão de Toulmin. In: NASCIMENTO, S. S; PLANTIN, C. (Org.). Argumentação e ensino de Ciências. 1ed.Curitiba: CRV, 2009, v. 1, p. 17-37.

SÁ, L. P.; KASSEBOEHMER, A. C.; QUEIROZ, S. L. Esquema de argumento de Toulmin como instrumento de ensino: explorando possibilidades. Ensaio: Pesquisa em Educação em Ciências, v. 16, p. 147-170, 2014.

SADLER, T. D.; DONNELLY, L. A. Socioscientific Argumentation: The effects of content knowledge and morality. International Journal of Science Education. v. 28, n. 12, 2006, p. 1463-1488.

TOULMIN, S. E. Os usos do argumento. São Paulo: Martins Fontes, 2. Ed., 2006.

VIEIRA, A. T. A dimensão avaliativa da argumentação na fala opinativa de profissionais de uma empresa em processo de mudança. Tese (Doutorado em Letras) - Pontifícia Universidade Católica do Rio de Janeiro, Rio de Janeiro, 2007. 160 f.

VIEIRA, R. D.; NASCIMENTO, S. S.; Argumentação no ensino de Ciências: tendências, práticas e metodologia de análise. Curitiba: Apris, 2007.

ZEMBA-SAUL, C. Learning to Teach Elementary School Science as Argument. Science Edcation. Science Education. v. 93, n.4, p. 687-719, 2009.

ZOHAR, A; NEMET, F. Fostering students' knowledge and argumentation skills through dilemmas in human genetics. Journal of Research in Science Teaching, v. 39, n.1, p. 35$62,2002$. 
Recebido: 2017-11-25

Aprovado: 2018-05-11

DOI: $10.3895 /$ rbect.v12n2.7401

Como citar: SILVA, A. C. T.; NARDI, R. Argumentos de professores de química e física sobre modelos de ensino: aspectos estruturais, dialéticos e retóricos. Revista Brasileira de Ensino de Ciência e Tecnologia, v. 12, n. 2, 2019. Disponível em: <https://periodicos.utfpr.edu.br/rbect/article/view/7401>. Acesso em: xxx.

Correspondência: Adjane da Costa Tourinho e Silva - adtourinho@terra.com.br Direito autoral: Este artigo está licenciado sob os termos da Licença Creative Commons-Atribuição 4.0 Internacional. 